\title{
Cluster as a form of international cooperation in the development of the Arctic region in the framework of the international innovation system
}

\author{
Inga Skvortsova ${ }^{1,}$, Roman Latyshev ${ }^{1}$ and Marina Oskolkova ${ }^{2}$ \\ ${ }^{1}$ Peter the Great Saint-Petersburg Polytechnic University, 29 Polytechnicheskaya, Saint-Petersburg, \\ 195251, Russia \\ ${ }^{2}$ Tyumen Industrial University, Volodarskogo str., 38, Tyumen, 625000, Russia
}

\begin{abstract}
The purpose of this article is to analyze the problems of the development of the Arctic space, the prospects for the development of international cooperation in this field, to determine the role of international clusters in the development of the subarctic region. The cluster is considered as an international organization defining development strategies for state cooperation, joint business activities, the formation of the information space in the framework of the international innovation system with the active use of the innovation potential of cluster members' cooperation.
\end{abstract}

\section{Introduction}

Nowdays, Russia pays increasing attention to the development of the Arctic. According to the President of the Russian Federation V.V. Putin, "Russia pays priority attention to the integrated development of its northern territories, implementies here a long-term strategy for expanding the logistics infrastructure, creates conditions for socio-economic and industrial growth (https://tass.ru/politika/4517324).

The Arctic is getting more and more involved in the globalization of the world economy. It develops trade and economic and advanced innovative scientific and technical cooperation.

It is impossible to estimate correctly the amount of wealth the Arctic shelf contains. In general, it is supposed that the bottom of the Arctic Ocean contains about $25 \%$ of the world's hydrocarbon reserves, and also rich deposits of diamonds, gold, platinum, tin, manganese, nickel and lead. The gradual depletion of developed energy deposits, as well as the impact of global warming on the earth's ecosystem, increases global competition for arctic natural resources. The Arctic states realized that the riches that the Arctic waters hold are the energy base for their future stable economic development. At the same time, we should not forget about the fragility of the ecosystem of the Arctic space. In 1996 the special organization was founded - the Arctic Council, representing eight Arctic states (Canada, Denmark, Finland, Iceland, Norway, Russia, Sweden and the United States). The Arctic Council aims to ensure

\footnotetext{
*Corresponding author: roman.fates@gmail.com
} 
the sustainable development of the Arctic: the preservation of biodiversity and the protection and rational use of the Arctic marine environment.

Russia has almost a third part of the Arctic territories. That the reason why our country will set the vector for the development of the north.

\section{Analysis of the Arctic, in terms of the development of geopolitical and economic processes}

The gradual depletion of developed energy deposits, as well as the impact of global warming on the Arctic ecosystem, increases global competition for arctic natural resources. In addition to Russia the territory of the Arctic is explored by such countries as Norway, the USA, Canada, Denmark, China, Korea and other countries which have no direct relation to the Arctic territories but show the considerable interest.

For Russia the territory of the modern Arctic is one of the main raw material reserves. A large percentage of the oil and gas resources of the Arctic fall at such fields as Urengoyskoye, Medvezhye, Ledovoye, Rusanovskoye, Pomorskoye and others. The major fields contain from 30 to 300 million tons of oil include Dolginskoye and Prirazlomnoye, the richest gas fields: Yamburgskoye, Shtokmanskoye, Medvezhye [5, 6]. More than 4 million tons of fish accounted for the total result of Russian fishermen for 2017. (https://tass.ru/vstrane/4558336). At the same time, Russia is open for constructive cooperation and forging a dialogue with other neighbor countries in the northern region.

Russia proceeds from the fact that there is no potential for any conflicts in the Arctic region. International standards clearly define the rights of coastal and other states and serve as a solid basis for working together to solve any problems. Evan such sensitive ones as the delimitation of the continental shelf in the Arctic Ocean, the prevention of unregulated fisheries in its central part, closed by exceptional economic United States, Canada, Denmark, Norway and Russia (V.V. Putin's speech at the plenary meeting of the IV International Arctic Forum "The Arctic: Territory of Dialogue" March 30, 2017, Arkhangelsk http://kremlin.ru/events/president/news/54149).

Norway is one of the main participants in international relations in the Arctic region. It acts as the most promising strategic partner for Russia. This is primarily due to the fact that Norway is a member of NATO and for this reason acts as a kind of advocate for the interests of Western European countries and the United States in the Arctic. At the same time Norwegian companies have an interesting experience for Russia in sphere of using large hydrocarbon reserves in cooperation with other countries and the implementation of complex innovative projects on the shelves of the northern seas. The total oil reserves of Arctic Norway are estimated at 10.2 billion barrels. This "Northern Neighbor", as well as Russia, claims the offshore sections of the Barents Sea.

Nowdays, the Norwegian authorities consider the Arctic as a region of stability and international cooperation in a changing world. The Norwegian Foreign Minister Ina EriksenSereide said about this at the international conference "Arctic Frontiers" in Tromsø (https://lenta.ru/news/2018/01/22/arctic/).

Norwegians are far advanced in questions of understanding the importance of the Arctic regions, both for the development of global geopolitical and economic processes, and for solving their internal economic problems. The development of Norwegian-Russian relations is includes the priority areas of their national interests.

In 2003 the Norwegian-Russian Chamber of Commerce was created. It is a nongovernmental, non-profit business association. The founders of the chamber are Norwegian and Russian companies and organizations that work actively in the field of NorwegianRussian foreign economic relations. The number of members of the chamber is growing 
steadily, indicating a rise in the authority of the Chamber among business circles in Norway and Russia [2].

The main objective of the Norwegian-Russian Chamber of Commerce is the development of economic relations between Norway and Russia. It needs certain time in sphere of the development of the Arctic region and the preservation of its ecosystems.

Within the framework of the Barents Sea Council a number of environmental problems in the Barents Region were solved. Three years later, in the city of Sortavala, a declaration was adopted, indicating the priorities for the Working Group on Environmental Issues in the coming years in the Barents Region. It is headed by Norway [4].

Norwegian businessmen say that Russia is one of the largest oil producers, but mostly production occurs on land, so the Russians have a need to study the Norwegian experience in oil production on the shelf. Norway has the skills of innovative technology offshore, which is extremely promising in the development of offshore fields. The Norwegian company Aker Solutions received an offer for the construction of two concrete platforms for the Sakhalin Energy Investment Company [4].

Representatives of INTSOK (a partnership of Norwegian oil industry enterprises) in Russia believe that Norwegian enterprises play a key role on the shelf in Russia. For Russia it is extremely important to involve Norwegian enterprises and technologies for offshore operations in the development of high-tech business in Russia in this area [3, 4].

\section{Cluster as a promising form of interstate cooperation in the framework of the international innovation system}

The process of development of high technology with international cooperation of countries in a single economic space is the most effective in the international innovation system.

The international innovation system is formed from the following elements (Open Innovation Infrastructure. A Guide to Creating and Using / Nurulin Yu.R., Skvortsova I.V. St. Petersburg: BHV-Petersburg, 2014 -148s. Silt.) (Table 1).

Table 1. Elements of international innovation system.

\begin{tabular}{|l|l|}
\hline \multicolumn{1}{|c|}{$\begin{array}{c}\text { Elements of the innovation } \\
\text { system }\end{array}$} & \multicolumn{1}{c|}{ International Innovation System } \\
\hline Subjects of innovation activity. & $\begin{array}{l}\text { Transnational corporations implementing innovative projects. } \\
\text { National companies working with foreign innovation } \\
\text { markets. International organizations defining international } \\
\text { development strategies. International innovation networks. } \\
\text { International societies. }\end{array}$ \\
\hline $\begin{array}{l}\text { Many support mechanisms } \\
\text { available to innovation actors. }\end{array}$ & $\begin{array}{l}\text { International innovation programs providing grants and } \\
\text { grants. Educational programs and mobility support programs } \\
\text { for the development of innovation. International innovation } \\
\text { forums and exhibitions. }\end{array}$ \\
\hline $\begin{array}{l}\text { Regulatory framework } \\
\text { governing aspects of } \\
\text { innovation. }\end{array}$ & $\begin{array}{l}\text { International agreements on the formation of joint } \\
\text { development tools or the introduction of restrictions on } \\
\text { certain types of activities or products. }\end{array}$ \\
\hline $\begin{array}{l}\text { Many innovation infrastructure } \\
\text { facilities. }\end{array}$ & $\begin{array}{l}\text { International organizations that provide financial support to } \\
\text { companies and individuals - subjects of innovation. } \\
\text { Specialized information systems focused on innovation. }\end{array}$ \\
\hline Many priorities of innovation. & $\begin{array}{l}\text { Formed and accepted by the international community } \\
\text { direction of scientific and technological development of } \\
\text { society, science and technology. }\end{array}$ \\
\hline
\end{tabular}


Based on the tab. 1, we can conclude that economic development with intercountry cooperation can be expressed in the creation of an international innovation cluster of a group of countries.

These days the development of an effective international cluster is directly linked to network cooperation. It allows us to reach a new level of competition and cooperation.

The creation of international networks includes:

- formation of new business models;

- formation of new international innovation systems;

- spreading of information and knowledge;

- transformation of regulatory and legal framework.

An example of such cooperation is the international consortium "St. Petersburg Clean Technologies Cluster for the Urban Environment" created in 2014, one of the founders of the cluster was the Norwegian company Nordic Commodities AS. Today members of the consortium are representatives of the countries of the Arctic Council: Finland, Denmark, Norway and Russia.

The cluster became the winner of the regional stage in St. Petersburg and the winner of the finals of the First All-Russian Competition of implemented projects in the field of energy saving and energy efficiency ENES 2014. It received the award of the Ministry of Energy of the Russian Federation as the best industry practice for the development and implementation of the Business Model for the implementation of the Norwegian Green Energy One (GEO) concept in St. Petersburg at the objects of the energy-efficient quarter cluster project.

Cluster members participate in the development of international cooperation in the field of education in close cooperation with northern countries. A project of the Nordic countries and Russia "Business and value-added value in the Arctic: interdisciplinary perspective" is realizing now. The aim of the project is to study the prospects for cooperation between the Nordic countries and Russia and to promote the development of knowledge in the development of the Arctic based on an interdisciplinary approach. Young people are actively involved in the Russian-Norwegian cooperation. During the project, a joint educational module was developed and an international experimental course for masters in Russia and Norway was held in 2017. One of the goals of the project is to strengthen cooperation with industrial enterprises by attracting representatives of the industrial sector of the economy to its implementation. [3]

In 2015, with the support of the Norwegian-Russian Chamber of Commerce, a group of students from SPbPU had an opportunity to visit Norway and get acquainted with the peculiarities of conducting innovative business in this northern country. A year later, SPbPU masters took courses in the town of Budo (Norway), within the framework of which they studied the methodology of foresight and scenario building for the development of the Far North until 2030 in areas such as aquaculture (fish farming), fishing (wild fish), mining, natural gas, oil, shipping, renewable energy and others.

\section{Conclusion}

"St. Petersburg Cluster of Clean Technologies for the Urban Environment" can be considered as:

1. An international organization defining international development strategies for cooperation between states, conducting joint activities, as an environment for the formation of the information space within the framework of an innovative international system.

2. As a basis for the development of institutions of government, market, business; a platform for the introduction and commercialization of new technologies, research and development, innovative ideas and innovative products in world markets; cumulative 
potential and conditions for combining efforts and resources in the field of priority research for the sustainable development of society, including in the Arctic

3. As a mechanism which promotes the spread of knowledge, information and innovation, the commercialization of innovations in this sphere, the formation within common economic space - united single innovation space.

Making a conclusion we can say that today the international cluster as a form of international cooperation in the development of the Arctic region is the most effective in the development of the international innovation system.

\section{References}

1. Lead maritime Petersburg, Information and analytical marine magazine 1, article "Ports and terminals - system element" (2012)

2. URL: http://www.tpprf.ru

3. I.V. Skvortsova, Yu.R. Nurulin, The development of the structure of high-tech business SPbPU, Proceedings of Conf. Polytech University, 130-132 (2006)

4. URL: http://www.norvegia.ru/News_and_events/happenings/

5. URL: http://rg.ru/2005/10/25/territoriya-spor.html

6. URL: http://www.arctic-info.ru/Encyclopedia/Rubric/strani-i-regioni

7. V.S. Belozubenko, Development of international collaboration in the sphere of innovations: the experience of European Union, Bulletin of the Donetsk State University of Management, 80-83 (2011)

8. A. Gekht, Development of scientifically-educational complex of Sweden and Finland in the second half of the XX century VII International Scientific and Technical and Methodological Conference «Actual Problems of Infotelecommunications in Science and Education» (2018)

9. A.S. Filatova, International cooperation of Russia in the field of innovation, IV International Scientific Conference, 40-43 (2015)

10. N.N. Semenova, Science. Innovation. Education, 8-24 (2008) ISSN: 1996-9953 